\title{
Corporeal violence in art-house cinema: Cannes 2009
}

\section{Published in Continuum: Journal of Media and Cultural Studies 30:6, 670-678}

\begin{abstract}
:
Taking 2009 Cannes Film Festival as a case study this article explores the narrative limits and possibilities of a global movement in art-house cinema: the portrayal of extreme corporeal violence - a movement that ranges from new French extreme to Asian extreme cinema. Cannes 2009 housed a collection of films that display extreme bodily violence, showing acts ranging from brutal rape and dismembering of the body to graphic scenes of torture, genital mutilation, and murders. The analysis of a selection of festival films provides an opportunity to track a transnational movement in which graphic scenes of violence become not only a convenient tool to further audience affect but also a means to reinforce the reality effect. This study, on the one hand, explores how films that display extreme bodily violence as an eruptive force seek memorability in the competitive arthouse film market. On the other hand, it suggests that on the eve of the 2009 global financial crisis, showing corporeal affect alludes to the disposability of bodies under a neoliberal economy obsessed with efficiency and adaptability. Hence, the ethical impulse that seeks the production of sympathetic bodies in the audience often goes hand in hand with the marketing of sensationalism.
\end{abstract}

Keywords: Violence in cinema, Cannes film festival, Affect, Body in film, Neoliberalism and the Body

Word count: 6269 words 
A common thread distinguished the award-winning films of the 2009 Cannes Film Festival: the representation of extreme and gruesome bodily violence. French director Jacques Audiard's Grand Prix winner prison drama A Prophet (2009) has a bloody murder scene with a razorblade hidden inside the culprit's mouth. Winning the best director award, Brillante Mendoza's Slaughter (2009) a Filipino film on police corruption, shows the abduction, beating, brutal rape and dismembering of a prostitute for nearly 45 minutes. Charlotte Gainsbourg won the best actress award for Lars von Trier's Antichrist (2009), a film with graphic scenes of torture consisting of genital mutilation with rusty scissors, a drill grinding through a leg, ejaculation of blood, and strangulation. Other films in competition, such as Gaspar Noé's Enter the Void (2009), has a graphic abortion scene, while Park Chan-Wook's vampire movie Thirst (2009) shows its main character with blood-filled blisters on his body, coughing up blood and draining corpses. Un Certain Regard winner Yorgos Lanthimos's Dogtooth ends with one of the characters brutally knocking out her dogtooth with a dumbbell. Bong Joon-ho's Mother (2009), which also competed in the Un Certain Regard section, shows the main character beating an old man with a shovel and setting him on fire. Film Comment reviewer Amy Taubin describes her festival experience as follows: 'As the flayed bodies and scalped heads piled up...one grew tired of questioning whether the viscera signified anything other than a desperate bid for attention by directors and the festival itself...'

Film festivals open up a space for public debates on "the first, the best, the most daring, or the most significant films..." (Cindy Hing-Yuk Wong 2011, 1). As Marijke de Valck remarks, scandals, spectacle and sensation have been central especially to Cannes, and have made it go beyond other film festivals in its international acclaim ever since the 1950s. Films that transgress boundaries and break taboos in Cannes have helped to increase the economic 
value of the selected productions and of the festival itself. Scandals about individual directors and films have been common at Cannes-including the portrayal of nudity and sex in the Antonioni films L'avventura and Blow Up in the sixties, protests against Jafar Panahi's imprisonment in Iran in 2010, and the screening of Les Indigènes (2006), which raised debates about the colonial era in France. Yet, a scandalous framework has never been so prominent in any other year of the festival. What makes 2009 a noteworthy year in terms of the festival selection and awards is that many critics and film scholars consider this group of films to be stirring a particular kind of scandal by providing a large palette of representations of corporeal violence. Pointing out the peculiarity of the 2009 selections, the Chicago Sun-Times film critic Roger Ebert asks, "Has there ever been a more violent group of films in the Official Selection? More negative about humanity? More despairing? With a greater variety of gruesome, sadistic, perverted acts?"

Along with the many film critics who observed the festival and compared the year's selections and awards to other festival years, Cindy Hing-Yuk Wong also chooses Cannes 2009 in her recent manuscript on film festivals as the particular year of "extreme violence and sexual portrayal," and as an example of how festivals welcome taboo-breaking and excessive subjects (90). Hence, Cannes 2009 provides a welcome opportunity for a more sustained analysis of a global moment in the representation of extreme bodily violence in contemporary art cinema. Such extreme forms of violence in cinema have so far been examined within a national (new French extreme, K-horror) and regional framework (Asian extreme), ${ }^{1}$ or in individual works, be they commercial films [The Passion of the Christ (2004), Hostel (2005), Saw series (2004-2010)] or those of certain auteurs (von Trier, Park Chan-Wook, Quentin Tarantino). As Cannes has

\footnotetext{
${ }^{1}$ Martine Beugnet's manuscript Cinema and Sensation (2007) and the edited volume on Asian "extreme" films Horror to the Extreme (2009) by Jinhee Choi and Mitsuyo Wada-Marciano are among the works that examine this movement in the 2000s.
} 
always been a showcase of movements in the global art-house filmmaking, analyzing the festival selections in 2009 provides an opportunity to explore how the portrayal of extreme bodily violence that gained currency in art-house films in the 2000s became a truly transnational phenomenon toward the end of the decade.

This article examines the representation of violence through three award-winning films in competition (A Prophet, Slaughter and Anti-Christ) and one film that competed in Un Certain Regard (Mother), covering two distinct festival sections that respectively showcase established directors and introduce young talents. Bodily violence in Bong Joon-ho's Mother and Lars von Trier's Antichrist aim to establish a tactile relationship with the spectator, a sensation that makes the films palpable and memorable commodities circulating in the global festival circuit. The depiction of extreme violence may lead to its commodification in the director's desire for attention in a competitive global art film market. While being incorporated into such commodification, extreme violence in film also has the potential to mobilize a unique critique of the effects of a competitive neoliberal market on the human body. The analysis of Slaughter and A Prophet suggests that pushing the limits of the human body in cinema may offer a window into the corporeal violence of neoliberalism — an economic system that introduces multiple forms of precarity, where the body either adapts and becomes flexible, or gets consumed and disintegrates.

Before examining the films screened in Cannes 2009, it needs to be acknowledged that cinema's interest in the body, the audience's sensation, and the shocking experience of screening the violation of the body have long attracted the interest of filmmakers. At the beginning of Luis Buñuel's Un Chien Andalou (1929) Buñuel himself plays the man who slits the eye of a woman. 
The spectator's gaze is reciprocal with that of the victim, and this connection increases the visceral effect of the slitting. The surrealists praised the new eye of the camera-Buñuel was crossing out the conventional gaze to engender new modes of seeing. Bodily sensation and violence have also been discussed in relation to some 'low culture' film genres such as horror, porn and 'weepie' melodrama_-'body genres' as film scholar Linda Williams calls them. The measure of these genre films' success has been the extent of their audience's bodily reaction, or the extent to which the audience's body mimicks the body on the screen, 'whether this mimicry is exact, e.g. whether the spectator at the porn film actually orgasms, whether the spectator at the horror film actually shudders in fear, whether the spectator of the melodrama actually dissolves in tears, the success of these genres seems a self-evident matter of measuring bodily response' (Williams 1991, 4-5).

A recent attempt to change the spectator's viewing habits like surrealism, often by adopting techniques from 'body genres', is the new French extreme. Both established and young directors' films such as Claire Denis’ Trouble Everyday (2001), Bruno Dumont's Twentynine Palms (2003), Marina de Van's In My Skin (2002), and Virginie Despentes and Coralie Trinth Thi's Rape Me (2000) are imbued with images of savage rape, knifing, sexual pathology, cannibalism, murder and compulsive self-cutting. Noting the synchronicity of these French films that 'thrill, frighten, gross out, arouse, or otherwise directly engage the spectator's body' (Hawkins 2000, 4), most critics suggested that these works offer gratuitous and sensationalist violence. Film scholar Martine Beugnet, however, categorizes them as the 'cinema of sensation' and suggests that extreme violence in some French films of the late 1990s and early 2000s build themselves against the Cartesian separation between the body and the mind, and call for a wider sense of perceiving reality and a more multisensory relationship to the image. For Beugnet, 
cinema of sensation may be distinguished by its effort to include more tactile details as 'a critique of the Western ocular-centrism... and a marked shift towards sensuous, embodied ... epistemologies' (Beugnet 2007, 74). Such cinematic practice, which weaves together the sensual and the conceptual, intends to go beyond the suppression of what belongs to the realm of body, 'the primordial forms of raw sensation: affect, excitation, stimulation and repression, pleasure and pain, shock and habit,' and beyond the privileging of a 'disincarnate eye and ear whose data are immediately objectified in the form of self-conscious awareness or positive knowledge' (Shaviro 1993, 26). Cinema of sensation intends to form a tactile relationship with its audience by becoming a sensual experience that pours out of the screen, (literally) touching its spectator and collapsing the border between the film and its audience.

South Korean Bong Joon-ho's Mother, which competed in Un Certain Regard section in Cannes 2009, is a striking example of tactile filmmaking in which the director makes an ongoing connection between the body and the mind, with his characters and the audience in an intense desire to break these dichotomies. In Mother the title character is an herbalist and unlicensed acupuncturist. Her mentally retarded son is accused of a murder without viable evidence and throughout the film she desperately tries to prove his innocence. The film, shot mainly from the mother's perspective, reflects a deep motherly affection, an affection bordering on obsession. The opening sequence shows the mother listlessly chopping dried herbs with a hinged guillotine cutter. Her fingers move closer to the blade as her attention is on her son standing across the street. Her distractedness is suspenseful as the spectator cringes in anticipation of seeing her finger chopped by the guillotine. Soon enough a car hits her son, and simultaneously she cuts her finger. The link between the mother and the son (and the mother and the spectator) is established in a tangible manner; the audience almost feels the cut, the mother runs out to help her son, and 
the minute she touches him she confuses her own blood with his. Throughout the film, not only emotions but also cognitive experiences are expressed in bodily terms: the boy massages his head continuously to remember the murder. The mother, on the other hand, tries to forget the instances of violence committed by her son and herself. Towards the end of the film, shot in a bus on a shaky handheld camera, a close up makes the spectator feel the fragility of her skin as the mother sticks an acupuncture needle into a strategic point on her own thigh so that she can expunge the bad memory of two murders. The closing shot shows the shining rays of the setting sun on the bus. The wavering image of the mother becomes a silhouette dancing along with the others in the bus. As her memory is erased, the cinematic image gets obscure and the protagonist is wiped out from the screen, along with her memory of violence.

Mother is ambiguous in its narrative resolution and the morality it presents as victim and perpetrator becomes increasingly unclear throughout the film. Just as Robert L. Cagle suggests in his comparison of extreme forms of violence in Hollywood and Korean cinema, as opposed to Hollywood movies (such as Kill Bill series), even when the theme is vengeance (as in Park Chan-Wook's trilogy), there is no redemption at the end of Korean films since there is no clearcut division between good and evil. For Cagle, the refusal of such morality and of comfortable closure (return to a world before and detached from violence) makes Korean films more horrifying and "extreme" for critics. In Mother the murders are depicted as eruptive possibilities within the everyday. The memory, which the main characters obliterate in order to return to the so-called normality of everyday life before the "interruption" of violence, is engrained in the spectators' minds through tactile details.

Austrian director Michael Haneke similarly aims to further the memorability of cinematic violence by exploring the levels and different channels of audience sensitivity. Haneke claims 
that our visual sensibility to violence is diminished by the flood of violent images on television: 'Our sensibility in the visual domain is further diminished by the flood of pictures on television, so that it is now very difficult to create pictures that leave a strong impression, let alone evoke reaction' (Haneke 2000, 174). The director's comment on media violence, the spectator's desensitization and the need to increase sensitivity to violence is rather commonsensical. What is worthy of attention is the method Haneke uses to extend the memorability of the representation of violence by expanding the stimuli over a relatively underexposed part of the spectator's body: the aural realm. For him, the spectator's ears are more sensitive than his eyes, which is a reason for his preference of aural sensation of violence over the visual; that is, hearing a victim's cries is much more effective than seeing his or her wounds, as 'the ear provides a more direct path to the imagination and to the heart of human beings. .' (Haneke 2000, 174). In White Ribbon, which won the Palme d'Or in Cannes 2009, one of the most violent scenes is the invisible flogging of a child behind closed doors. The spectator hears the whip and the boy's muffled screams on a static camera situated in front of the closed white door of the pastor's living room. As the cinematic ear is privileged over the cinematic eye, hearing provides a fresher pathway to memory and attention.

Memorability of the image and of the film itself must also be considered in relation to a film's commodity value within the global market, as the representation of violence may become a way to enter into international circulation by way of an 'affect economy' (Hagman 2007, 36). As Hampus Hagman explains, especially for art-house films to profit, 'there must be something that persists after the viewing is over, something that makes you want to talk about [the film]. What better way to do this than through good old shock tactics' (Hagman 2007, 37). Profit is embodied through cashing in on the visceral effect. Such embodied profit can be observed in the 
marketing of Asian films that depict corporeal violence in late 1990s early 2000s. Works such as the Korean film Oldboy (2003) — part of Park Chan-wook's vengeance trilogy_in which the main character cuts of his own tongue to atone for his past guilt that led to his present incestuous relationship with his daughter; the Japanese production Audition (Miike Takashi, 1999), which has numerous scenes of torture and bodily mutilation; and Hong Kong production Dumplings (Fruit Chan, 2004) whose title refers to special rejuvenation dumplings made out of unborn fetuses from an abortion clinic; have been promoted as "extreme" in order to draw a certain cult audience. Examining the sales strategies of Tartan films - a London based distributor of Asian films in the USA, UK and Ireland - Chi-yun Shin concludes that “...for now, it is, most of all, the ability to shock that sells East Asian films in the West" (Shin, 99). The embodied violence becomes memorable and marketable as it persists and travels between spectators as they share with and advocate the unique experience to other cult film enthusiasts.

Lars von Trier's Anti-Christ, for which Charlotte Gainsbourg won the best actress award in Cannes 2009, has been similarly promoted as a scandalous visceral experience. Xan Brooks provocatively declares, 'nothing-but nothing-could prepare us for the film,' under the attentiongrabbing title of his review for The Guardian, 'Antichrist: a work of genius or the sickest film in the history of cinema?' An unnamed couple, taken by guilt and grieving after their baby's accidental death, retreat to 'Eden,' their isolated cabin in the woods. Except for the closing scenes, Antichrist is dominated by the male therapist/husband's struggle to contain the trauma of his female patient/wife. The director seems to propose the need to cross of the boundaries of secular humanist reason and textbook treatments of trauma in order to explore the (sometimes evil) connections between the mind and the body as a result of strong emotions such as desire, grief and despair. The film, however, is situated on the slippery slope between representing the 
female character as a case of trauma that defies psychoanalytic treatment, and a figure of mythical evil incarnated. So while the film questions the boundaries between the cognitive and the emotional, and the realms of body and mind, it assigns this division to the usual suspects: She represents the emotion, the evil, and the wildness of nature that needs to be tamed or rather sacrificed to restore the order, while He as the survivor-husband represents reason, peace, and the restored order. The resolution of the film ends up affirming the Cartesian divide.

The eventual otherization of the carnal can be foreseen in the beautifully-shot opening scene. von Trier uses a special camera to shoot a crystal clear and fluid black and white image in extremely slow motion. While the soundtrack of an aria by Handel is playing, the couple make love in the bathroom under the running water. The crosscutting shows their toddler moving towards the open window, then falling, in feather-light slow-motion into the powdery snow. The beauty of the image contrasts with the horror of the child's death. The slow motion gives a different sense of temporality, and the sense of the couple's sexual pleasure (especially hers with the frequent close ups) is heightened along with the sense of their culpability (again, especially hers, as she seems to be situated in a position to see the toddler going towards the window). Slow motion gives the sense that the fall of the child could have been prevented. The sex scene representing carnal pleasure becomes ferocious in the light of the crosscut to the fall, an event that initiates more violence to come. In the last scenes of the film, She drills her husband's leg and attaches a concrete millstone to it, cuts her own clitoris in a close up, and, finally, $\mathrm{He}$ strangles her and burns her body (an allusion to witch trials). The spectators are subjected to a sensational experience, later to be incorporated into the 'affect economy.' 
The Village Voice reporter from Cannes suggests that behind the economic motivation to extract audience affect is the need to further the reality effect as a response to an ontological crisis in the cinematic representation of reality:

if the most characteristic films selected for competition in Cannes were put under psychoanalysis, a fundamental, ontological anxiety might be revealed: Do movies still move us? Does cinema still have the power to thrill? What does it take to provide a visceral experience?... Is the medium itself alive?

An increasing anxiety about the referentiality of the cinematic image seems to stimulate scenes of extreme corporeal violence to anchor realism since the 'spectatorial body whose sensations and affects promote the effect that the image is real' (Peucker 2007, 164). Physical violence becomes the ultimate realist manner through which the film touches its spectator 'to reveal what is violent about violence' (Seel 2005, 190). As philosopher Martin Seel argues, violence has a special place in the representational realm: it is the stylistic tool that creates the illusion of reality with its visceral effect, as the spectator feels it on his or her body. Corporeal violence gives the audience a slice of reality, as the body seems to have become the new bearer of reality, particularly the wounded and violated body. 'Deleuze asks, if the true world no longer exists, and the world is not what it appears to be (in the present), what is left to believe in? The "Nietzschean" answer he gives is: "bodies"” (Pisters 2003, 84-85). Hence, according to Deleuze, the body is 'one of the last things we can still believe in' (Pisters 2003, 85).

Indeed in Brilliante Mendoza's Slaughter, the undercover police violence and the violated body of a prostitute becomes the bearer of a certain 'Filipino reality.' As the winner of the best director award in Cannes 2009 explains,

...if you're talking about how is life in Manila, it's basically like this because... we are ... 90 million Filipinos and 85 percent belong to the low income bracket. So I think this is the best representation of the Pilipino, not the 5 percent or 10 percent who are very rich (Mendoza 2009). 
Slaughter starts with bright and colorful daytime images of Manila shot on $35 \mathrm{~mm}$, including a happy day of a humble marriage for the protagonist. Peping, studying to be a police officer (throughout the film he ironically wears a t-shirt with the label 'School of Criminal Justice: Integrity_Once Lost, Forever Lost') needs supplemental income. Hustled into a car with a group of undercover policemen, he embarks on a mysterious operation, which consists of kidnapping a prostitute named Madonna, beating and gagging her, and driving out into the country to a secluded hideout. Before their arrival to the house where they eventually murder Madonna, there is a long sequence of dark, blurry and suspenseful night-time travel which contrasts with the bright daylight images of Peping's wedding. Shadow-like and barely-revealed night scenes in the van are shot on high-definition video with natural lighting. The audiences' inability to see clearly corresponds with Peping's inability to know what will happen next and how he should be responding to it. The main character's ethical uncertainty is reflected in the shaky handheld camera, natural lighting (dim and dark), hearing his short breath and anxiously moving body parts fragmented in extreme close ups. The shimmering nightscape as viewed through the car windows (billboards extolling Christ along with consumer products, the neon burst of shady nightspots) show the landscape of chaotic commodification.

In the country house, Peping looks on in horror as the men ridicule the aging prostitute Madonna, who allegedly owes them drug money charging her with being a used-up piece of meat. While she is repeatedly raped, she is also harangued for being no longer good for sex. Finally she is hacked up into pieces - like a chopped up chicken shown in the opening sequence - and her corpse is disposed of. The men place her fragmented body parts in separate plastic bags and throw the bags one by one out of the van as they travel back to Manila. 
Madonna's exploited and objectified body had become undesirable and inconsumable as it aged and became 'infected' with drugs; the value of her life diminishes along with the value of her flesh. The fragmentation of her corpse and plastic-bagging of the fragments emphasize her refuse status. In the last sequence, we hear on a car radio the news about the discovery of Madonna's fragmented body parts. The market finds a way to make a commodity even out of this disposal. If her body cannot be sold anymore, then her story becomes a commodity in the media. She becomes a news item at the end of the film and the cycle of consumption continues.

While Madonna's drug-infected and aging body represents the dissected postconsumption waste, the police force assumes efficiency and adaptability by outsourcing itself as private security for a drug lord so as to make money on the side. As Slaughter depicts, within cinematic realism that places the wounded body at its center, the displays of ruthless violence frequently point to a certain corporeal regime within the neoliberal economic and social structure: a regime whose exploitative processes renders the human body disposable unless it continuously adapts itself to the expanding demands of the market and threats of precarity. As political theorists Judith Butler and Athena Athanasiou argue, in the neoliberal sociopolitical context dispossession goes hand in hand with the need for management of the self:

In the context of neoliberal forms of capital...bodies (that is, human capital) are becoming increasingly disposable, dispossessed by capital and its exploitative excess, uncountable and unaccounted for. At the same time they are individuated and subjectivated through subtler and reflexive biopolitical techniques of self-formation, selfcare, self-fashioning and self-governance (29).

As a response to the relations of power that introduce ever-new forms of economic precarity, an individual's identity and body are forced to become ever flexible and adaptable, and are repeatedly reinvented. Sociologist Richard Sennett describes the kind of individual that the neoliberal economy outlines and creates as an individual who "can prosper in unstable, 
fragmentary social conditions" and respond to various challenges that require flexibility in terms of identity, temporal horizon (short-term and part-time jobs), type of occupation and talent (being able to move among different careers). One's relationships to the self and the environment are continuously challenged, changed, or even eradicated as "the individual may have to improvise his or her life-narrative, or even do without any sustained sense of self " (Sennett 2006, 4).

Such absence of a "sustained sense of self" (or Sennett's "corrosion" of the character) (Sennett 1998) and improvisation of a life-narrative can be best observed in Jacques Audiard's Grand Prix winner A Prophet, a prison coming-of-age drama about French-North African Malik, who enters a French prison for six years and follows a trajectory from an underdog petty criminal with no promising future, to a kingpin of profitable illegal activities. When Malik first sets foot in prison, he starts a job in the workshop sewing jeans, as part of the prison-industrial complex. Soon the industrial aspect of the prison departs from view and spectators are confronted with a carceral realm that builds its own order from within, as Malik starts serving the Corsican inmate gangsters who rule the prison. Malik becomes a product of the prison complex, not disciplining bodies in the traditional sense, but enabling upward mobility for a capable multi-tasking criminal who learns how to murder and deal drugs, and eventually upsets the Corsican rule in prison as he establishes his own dominion.

The director privileges Malik's point of view, as the camera follows him everywhere and the events are seen from his perspective, frequently in POV shots; yet so little is revealed about Malik's life before prison. The opening sequence shows Malik's hands and then his face in curtailed frames. The camera falls upon him like a surveying spotlight, and then the soft-focus circle gives his distinct point of view. Malik's eyes are timid, his vision is raw, and he does not 
have good depth perception of his surroundings. He sees the world through a keyhole, claustrophobic and narrow, and the spectator too sees him from a narrow and limited angle. The film presents Malik as a subject without a past, without memory or history, no friends or family outside, and no education or resources; he only has a name and an ethnic identity, which due to the connections he makes shifts between the two groups-the Corsicans and Arabs. Malik comes to prison as a blank character except for the reason of his sentence-attacking a police officerand for the history of violence ingrained on his body — the scars that are seen when he is naked. His first training is in murder, as a member of the Corsican mafia teaches him how to hide a razor blade in his mouth, and then how to kill with the razor blade. Malik is the product of prison education —not rehabilitative but adaptive.

The protagonist's learning curve and adaptation is best represented in a comparison of the film's two scenes of violence. The first murder is clumsy, as a low angle shot that follows the crime exaggerates the size of the corpse and conveys the sense of weight that the murder creates on Malik's conscience which is trapped and dwarfed by the corpse. In opposition to this scene, his last act of violence — a gunfight scene after which Malik finally turns the tables on his Corsican boss Cesar-shows him as a professional criminal. The scene is highly choreographed, shot in slow motion with no sound. At a crucial moment when Malik gets into a car to kill the four bodyguards of a mafia kingpin, an overhead shot shows the hero smiling peacefully back at the camera, thus breaking the fourth wall. By this time he learns the trade and wins over the film narrative. His confident and even playful gaze back at the camera reflects an ultimate control of the performance/ killings while slow motion demonstrates his control over time. As he washes off the victims' blood from his hands in the next scene, he is calm and contemplative. 
Through successive trainings, Malik becomes the epitome of adaptation, flexibility and risk-taking. He represents the passage from Foucault's disciplinary society (from the rehabilitated inmate) to the new post-fordist mode of subjectification (to the self-formed, selffashioning agent). When asked why he is working for the Corsicans he answers, 'I work for myself!' Improving his talents at various levels (teaching himself the Corsican language, becoming proficient in murder, drug dealing, and mediation between different groups of inmates), he becomes the expert on himself, 'responsible for managing [his] own human capital to maximal effect' (Fraser 2003, 168). Like Peping, the police academy student who subcontracts his services to a mafia boss in Slaughter, he is the product of a post-fordist society with flexible and fluid morals and a temporal horizon of 'no long term.' (Fraser 2003, 169).

The desirable characteristics of the human subject within the neoliberal market society (competitiveness, efficiency, and adaptability) reflect the subjective consequences of the “organizing principles" of the neoliberal market—-"flexibilization, deregulation, and privatization" (Griffin 230). Following these organizing principles of neoliberalism, regulation takes the meaning of flexibility and moral elasticity rather than a Foucauldian sense of disciplinarity, the model of discipline supported through institutional structures such as family, school, prison and psychiatric hospital (Fraser 2003). The destruction of bodies in most of the Cannes 2009 films takes place in the sites of the Foucauldian capillary power, all corrupted and disintegrated: in Slaughter the police force, instead of bringing order and justice, represents the crux of criminality and corruption as they do side jobs for the mafia. A Prophet's prison is far from being a place of rehabilitation--it is a training ground into organized crime. In Anti-Christ the violence erupts during the process of healing from trauma when the relationship between the husband and wife turns into that of therapist and patient, and the nuclear family turns into a 
psychiatric hospital until it explodes brutally. The protagonist in Mother is forced to take the role of a detective due to the incompetence and neglect of the justice system. As a result of her travail the police send her son back home and frame another disabled boy. What connects these films is that their representation of violence shows how subjects are forced to shape and adapt themselves to the deregulated neoliberal sociopolitical contexts that present multiple and increasing forms of precarity.

\section{Conclusion}

When films are closely aligned with capital, could bodily violence in cinema- the flaying and opening of bodies, the spilling of blood—show anything meaningful about the relationship between corporeality of the subject and contemporary economics beyond sensationalism? To some extent, the aesthetics of violence produce a violent-chic that reinforces memorability of the image through sensational representation of the body's vulnerability and injurability. Depicting such vulnerability of the body, however, could also make a reference to the very violence of commodification under the global neoliberal economy. Stylistic violence may provide a commentary on the violent disposability of bodies as well as their adaptability under post-fordist economy obsessed with efficiency, competition, and risk-taking.

The films analyzed here, by resorting to sensation, affect and extreme violence, attach themselves to an index of reality as defined by pain and the wound, and convey the violence of the neoliberal corporeal regime. Shot in 2008, A Prophet and Slaughter in particular convey the embodied effects of the global financial crisis: an historical turning point at which the disastrous consequences of neoliberal capitalism were painfully manifested. It is not a coincidence that the central characters of these two films are a young student, an aged prostitute, and a French inmate 
of North African descent: signifying class, sexual or ethnic marginalization. Films such as Slaughter take the initiative to show 'a truer image...images that convey the full horror and reality of [human] suffering' (Butler 2006, 146), especially those of underrepresented characters. The intention to tackle this challenge takes the body to the edge. The ethical premise of depicting violence in order to show the disposability of the human body within the current economic and social structure, however, may very well be aligned with further objectification and cashing-in on the body in the festival circuits.

It goes without saying that corporeal violence in cinema may be conceptualized very differently in art-house films with more clearly outlined resistant politics such as Steve McQueen's Hunger (2008), which depicts the violent treatment of the IRA inmates in Maze Prison in Northern Ireland leading up to their hunger strike (it premiered and was awarded the Camera d'Or at Cannes 2008). The analysis of the Cannes 2009 films however, shows that when it comes to festival films that depict extreme corporeal violence, the sensual and ethical premise that aims for the production of sympathethic bodies in the audience and the marketing strategy of sensationalism may not be easily distinguished. Despite (and maybe as a result of) their tendency to capitalize on bodily violation, these films are able to show how neoliberal capital expands into the body. As film scholar Jonathan Beller explains, 'in a fully globalized situation, capital expands not outward, spatially and geographically, but into the body, mining it of value' (Beller 1998, 92). By taking the body to the edge of its limits, both psychologically and physically, these films have the potential to present the limits, efficiency and disposability of the human body within the current economic structure of commodification that capitalizes on the adaptability of the body. Thus, on the one hand, films capitalize on bodily violation; on the other hand, they represent how neoliberal capital shapes, changes and invades the body. In a context where 
'dynamism of capital...continuously produces new limits, to continually open up new trajectories that it has to colonize' (Mezzadra 2007), aesthetics of violence both embody this limitless capital and criticize its crushing effects on the human body.

\section{Acknowledgements}

I would like to thank Rina Bliss, Saida Hodzic, Dore Levy, Alexis Rappas, Katerina Seligmann and Ipek Tureli for their insightful comments on an earlier draft, and the two anonymous referees for their productive suggestions for revision. I am also grateful to the editors John Tebbutt and Panizza Allmark for their help and advice throughout the publishing process.

\section{References}

Beller, Jonathan. 1998. "Capital/ Cinema.” In Deleuze and Guattari: New Mappings in Politics, Philosophy and Culture, edited by Eleanor Kaufman and Kevin Jon Heller, 77-95. Minneapolis: University of Minnesota Press.

Beugnet, Martine. 2007. Cinema and Sensation: French Film and The Art of Transgression. Carbondale: Southern Illinois University Press.

Brooks, Xan. 2009. "Antichrist: A Work of Genius or The Sickest Film in the History of Cinema?" The Guardian, 16 July. Accessed 12 January 2015.

http://www.theguardian.com/film/2009/jul/16/antichrist-lars-von-trier-feminism

Butler, Judith. 2006. Precarious Life: The Powers of Mourning and Violence. London: Verso.

Butler, Judith and Athena Athanasiou. 2013. Dispossession: The Performative in the Political. Cambridge: Polity.

Cagle, Robert L. 2009. "The Good, the Bad and the South Korean: Violence, Morality and the South Korean Extreme Film," In Horror to the Extreme, edited by Jinhee Choi and Mitsuyo Wada-Marciano, 123-144. Hong Kong: Hong Kong University Press.

Choi, Jinhee and Mitsuyo Wada-Marciano. 2009. Horror to the Extreme: Changing Boundaries in Asian Cinema. Hong Kong: Hong Kong University Press. 
Ebert, Roger. 2009. “Cannes \#10: And, At Last, the Winners are..." Roger Ebert's Journal, 24 May. Accessed 15 July 2015. http://www.rogerebert.com/rogers-journal/cannes-10-and-at-lastthe-winners-are

Fraser, Nancy. 2003. "From Discipline to Flexibilization? Rereading Foucault in the Shadow of Globalization." Constellations 10: 160-171.

Hagman, Hampus. 2007. “"Every Cannes Needs Its Scandal': Between Art and Exploitation in Contemporary French Film." Film International 5 (29): 32-41.

Haneke, Michael. 2000. "71 Fragments of a Chronology of Chance: Notes to the Film." In After Postmodernism: Austrian Literature and Film in Transition, edited by Willy Riemer, 171-175. Riverside: Ariadne.

Hawkins, Joan. 2000. "Sleaze Mania, Euro-trash and High Art: The Place of European Art Films in American Low Culture." Chap. 1 in Cutting Edge: Art-Horror and the Horrific Avant-Garde. Minneapolis: University of Minnesota Press.

Hing-Yuk Wong, Cindy. 2011. Film Festivals: Culture, People, and Power on the Global Screen. New Brunswick: Rutgers University Press.

Hoberman, James. 2009. "A Final Report from the Cannes Film Festival 2009," Village Voice, 26 May. Accessed 20 December 2014. http://www.villagevoice.com/2009-05-27/film/a-finalreport-from-the-cannes-film-festival-2009/

Mezzadra, Sandro. 2015. "Racism, Migration and Citizenship in Europe." Seminar I: Etienne Balibar and Sandro Mezzadra in Conversation, 25 May. Accessed 15 January 2015. http://www.darkmatter101.org/site/2007/08/05/racisms-migration-citizenship-in-europe/

Mendoza, Brilliante. 2009. "Mendoza's Real Philippines.” Interview with Associated Press, 27 May. Accessed 23 December 2014. https://www.youtube.com/watch?v=Xmh57Bvj35Q

Peucker, Brigitte. 2007. "Images of Horror: Taste, Cannibalism and Visual Display." Chap. 9 in The Material Image: Art and The Real in Film. Stanford: Stanford University Press, 2007.

Pisters, Patricia. 2003. The Matrix of Visual Culture: Working with Deleuze in Film Theory. Stanford: Stanford University Press.

Quandt, James. 2011. "Flesh and Blood: Sex and Violence in Recent French Cinema." In The New Extremism in Cinema: From France to Europe, edited by Tanya Horeck and Tina Kendall, 18-25. Edinburgh: Edinburgh University Press.

Seel, Martin. 2005. "Variations on Art and Violence." Chap. 5 in Aesthetics of Appearing. Stanford: Stanford University Press.

Sennett, Richard. 2006. The Culture of New Capitalism. New Haven: Yale University Press. 
Sennett, Richard. 1998. The Corrosion of Character, The Personal Consequences of Work in the New Capitalism. New York: Norton.

Shaviro, Steven. 1993. Cinematic Body. Minneapolis: University of Minnesota Press.

Shin, Chi-Yun. 2009. "The Art of Branding: Tartan 'Asia Extreme' Films." In Horror to the Extreme, edited by Jinhee Choi and Mitsuyo Wada-Marciano, 85-100. Hong Kong: Hong Kong University Press.

Taubin, Amy. 2009. “Cannes 2009: Take One.” Film Comment, July/ August. Accessed December 2014. http://www.filmcomment.com/article/cannes-2009-take-one

de Valck, Marijke. 2007. "Cannes and the 'Alternative' Cinema Network." Chap. 2 in Film Festivals: From European Geopolitics to Global Cinephilia. Amsterdam: Amsterdam University Press.

Williams, Linda. 1991. "Film Bodies: Genre, Gender, and Excess.” Film Quarterly 44 (4): 2-13. 